\title{
The Australian Economy in 2019-20: Slower growth, record low interest rates and a changing housing landscape
}

\author{
Sarantis Tsiaplias and Jiao Wang*
}

\begin{abstract}
Economic activity in Australia slowed considerably in 2018-19, with domestic demand growth halving and unemployment rising. Consistent with the slowdown, both consumer and wage inflation have remained weak. There was a synchronised growth slow-down across major economies, largely underpinned by the on-going USChina trade war. Central banks have responded to weak growth by cutting rates. The US Federal Reserve cut its target for the federal funds rate three times in 2019, as did Australia. To date, record low Australian interest rates have been associated with additional housing-related debt and asset price appreciation.
\end{abstract}

\section{Introduction}

Growth in the Australian economy slowed considerably in 2019, falling from an annual growth rate of 2.7 per cent in 2018 to approximately 1.7 per cent in 2019 (Table 1). Domestic final demand in 2019 grew at less than half the rate observed in 2018 (from annual growth of 2.8 per cent to an expected growth rate of 1.0 per cent). It is also concerning that the unemployment rate, after falling to as low as 4.9 per cent in February 2019, is now hovering at between 5.2 and 5.3 per cent. Unsurprisingly, both consumer price inflation and wage inflation are weak.

The outlook for the Australian economy in 2020 is also uncertain, with only moderate growth expected for output, given the forecasts of moderate performance of household consumption and domestic final demand. Consumer inflation and wage growth will likely continue to be weak.

Growing concerns over international economic conditions led to a spate of interest rate cuts in the US during 2019. After hiking its target rate for the ninth consecutive time in December 2018, the Federal Reserve cut its target for the federal funds rate three times in 2019 (to a lower limit of 1.5 per cent in November). The Reserve Bank also cut its target rate, to some extent as a response to the US cuts, three times in 2019. The cash rate in Australia is now at a record low 0.75 per cent after beginning the year at 1.5 per cent.

Despite record low interest rates, consumers in Australia have, thus far, been largely unresponsive in terms of their expenditure. Annual consumption growth is

This is the author manuscript accepted for publication and undergone full peer review but has not been through the copyediting, typesetting, pagination and proofreading process, which may lead to differences between this version and the Version of Record. Please cite this article as doi: 10.1111/1467-8462.12367.

This article is protected by copyright. All rights reserved. 
expected to fall to 1.4 per cent in 2019, compared to a significantly higher 2.6 per cent for the previous year.

* Melbourne Institute: Applied Economic \& Social Research, the University of Melbourne, Victoria 3010. Corresponding author: Sarantis Tsiaplias (stsiaplias@unimelb.edu.au). We thank Guay Lim, Ian McDonald and Ross Williams for helpful comments.

Table 1: Indicators of Australian Activity

\begin{tabular}{|c|c|c|c|c|}
\hline & \multirow[b]{2}{*}{$2019^{b}$} & \multicolumn{3}{|c|}{$2020^{a}$} \\
\hline & & $M I^{c}$ & Low $^{d}$ & High $^{d}$ \\
\hline GDP & 1.7 & 1.7 & 2.0 & 2.9 \\
\hline Consumption & 1.4 & 1.5 & 1.4 & 2.3 \\
\hline Domestic Final Demand & 1.0 & 1.0 & - & - \\
\hline Unemployment rate & 5.2 & 5.3 & 5.0 & 5.6 \\
\hline Employment growth & 2.3 & 1.2 & - & - \\
\hline Wage Cost Index & 2.2 & 2.0 & 2.3 & 2.6 \\
\hline Headline inflation & 1.5 & 1.8 & 1.6 & 2.2 \\
\hline Underlying inflation & 1.5 & 1.6 & - & - \\
\hline 90-day bill rate ${ }^{\mathrm{e}}$ & 0.9 & 0.6 & 0.3 & 0.8 \\
\hline
\end{tabular}

Notes: (a) Forecasts (b) Estimates, (c) MI denotes Melbourne Institute, (d) Based on published forecasts in Consensus, December 2019, (e) As at end of year.

Sources: Melbourne Institute and Consensus Forecasts.

As in previous Reviews, Section 2 is devoted to a discussion of international economic developments. In this article, we focus on the China-US trade war and its effects on US and Chinese economic growth. Prospects for the Chinese economy remain a key source of risk for the Australian economy.

In Section 3, we summarise developments in the domestic real economy, in addition to developments in labour and financial markets.

Section 4 discusses the ramifications of lower interest rates for households, with a particular emphasis on housing. A likely outcome associated with record low interest rates is asset price inflation for both property and equities. Given the underlying weak fundamentals both domestically and overseas, the sustainability of these rises is, however, questionable.

Following on from the wrapping up of the Royal Commission into the banking sector, it appears that upgraders and investors are tentatively re-entering the housing market, with residential lending levels starting to rise again after sharp falls in the first half of 2019. This may curtail the increased first home owner activity observed over much of 2019.

The significant changes observed in the housing landscape over the past 25 years are also examined, particularly since they are likely to be playing a role in the extent to which consumers are willing to spend on discretionary items. 


\section{International Influences}

The world economy deteriorated in 2018-2019. Growth in major economies was in a synchronised slow-down in 2019, following sharp declines in the last three quarters of 2018. World merchandise trade, industrial production and the global manufacturing sector were substantially weaker in 2018-2019. Increased trade tariffs, rising policy uncertainty and weak business confidence were important factors underlying weak global economic conditions in 2019. The International Monetary Fund (IMF) has projected (in its October World Economic Outlook (WEO)) that the global economy will grow at 3.0 per cent in 2019, the lowest since the Global Financial Crisis (Figure 1).

Figure 1: Global Growth (\%)

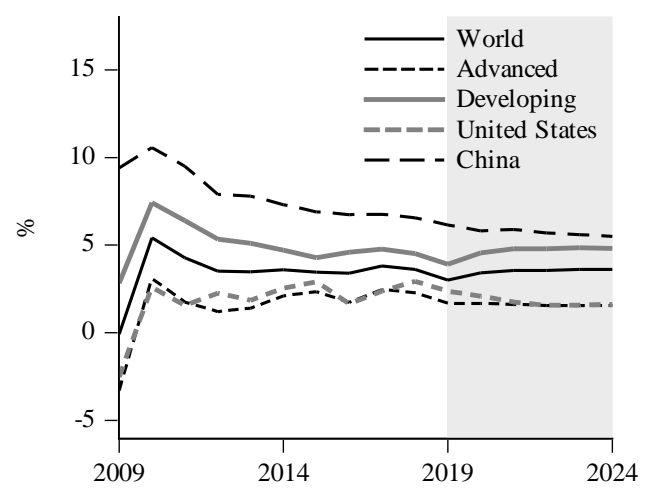

Source: IMF World Economic Outlook, October 2019.

Note: grey area are IMF forecasts.

The biggest factor that undermined the global economic and trade performance in 2018-2019 is the on-going trade war between the United States and China. The trade dispute, initiated by the Trump administration in the first quarter of last year, intensified into a trade war in June and has had several rounds of escalations and temporary truces over its (still undetermined) course. ${ }^{1}$ The United States has so far applied tariffs on US\$550 billion worth of Chinese goods while China has placed tariffs on US $\$ 185$ billion worth of goods imported from the United States.

The impact of the on-going trade war between the world's largest two economies appears to have gone beyond weakening world economic and trade growth. It may have also led to changes in the global supply chain with businesses in Europe and Asia relocating their investment and exports to their own regions. The heightened policy uncertainty around the-trade war has made firms delay long-term investment and expenditures and this is likely to have long lasting effects on global economic activity.

Other factors such as idiosyncratic shocks to the automobile industry and macroeconomic stress in several emerging market economies such as Turkey, Argentina and Iran have also weighed on the slowdown of the global economy. In particular, the automobile industry took a downturn in 2018 for the first time since the GFC due to the fall in demand from China and the rollout of new carbon emission

This article is protected by copyright. All rights reserved. 
tests in Europe. Studies estimate that the contraction of the automobile industry contributed about one-tenth of the slowdown in GDP growth in 2018 and about as much as 0.5 percentage points from global trade in 2018 (see IMF (2019) and Berns (2011) for details).

The subdued economic outlook for 2019-2020 and rising policy uncertainty and downside risks have motivated a synchronised monetary easing among several major economies. Policy interest rates in the United Kingdom and Australia are below 1 per cent while interest rates in Japan and the Euro area are negative. The extremely low rates of borrowing are expected to remain in the medium term, which may encourage excessive borrowing and risk-taking.

\subsection{The United States}

The U.S. economy is projected to grow at 2.4 per cent in 2019 and moderate to 2.1 per cent in 2020, according to the IMF October WEO (IMF 2019). The October forecast for output growth in 2019 is 0.2 percentage points down from the July projection and 0.1 percentage points up from the April projection. The revisions reflect the uncertainty around the growth trajectory of the U.S. economy as the trade war with China develops over time. Overall, the U.S. economy gained momentum in the first half of 2019. Investment and exports remained sluggish while consumption and employment were strong.

Much of the growth momentum in 2018-2019 came from two policies. One is a new budget deal passed in August that increased the U.S. budget deficit and raised the debt ceiling for the next two years. This makes up for the diminishing effects of the 2017 fiscal stimuli. The other is the pre-emptive Federal Funds rate cuts in July, September and October, bringing the policy rate back to its 2018 March quarter level. The Federal Reserve has signalled holding off further rate cuts in 2019.

The outlook for the U.S. economy in 2019-2020 remains uncertain with significant downside risks. The interest rate spread between the Treasury 10-year bill and 3month bill has been steadily falling (including into the negative region). In the past few decades this has been a strong forward indicator of economic recessions in the U.S. economy, with negative spreads implying extreme pessimism about the prospects of an economic recovery (Figure A). (\%)

Figure A: 10-Year Treasury Constant Maturity Minus 3-Month Treasury Constant Maturity, Monthly

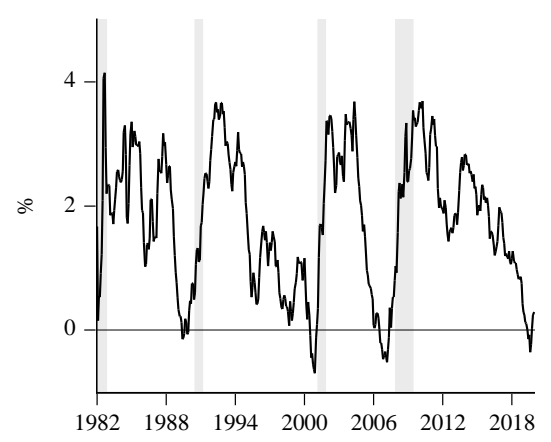

This article is protected by copyright. All rights reserved. 


\subsection{China}

The IMF projects China's output growth to be 6.1 per cent in 2019 and 5.8 per cent in 2020, a downward revision from projections made in April and July. The slowdown of the Chinese economy is due to a number of external and internal factors. The trade war with the U.S. took a toll on China's exports to the U.S., although its exports to non-U.S. countries increased at the same time. Domestically, the structural deleveraging policies ${ }^{2}$ have continued to rein in the debt growth of state-owned enterprises and local government. Regulatory tightening of the property market continued in 2018-2019 with property prices in tier 1 cities, such as Beijing, flattening relative to the rising 70-cities average price. (Figure 2).

Figure 2: China's Residential Property Price for Beijing (Index, 2015=100) and 70-cities Average (Index, 2010=100)

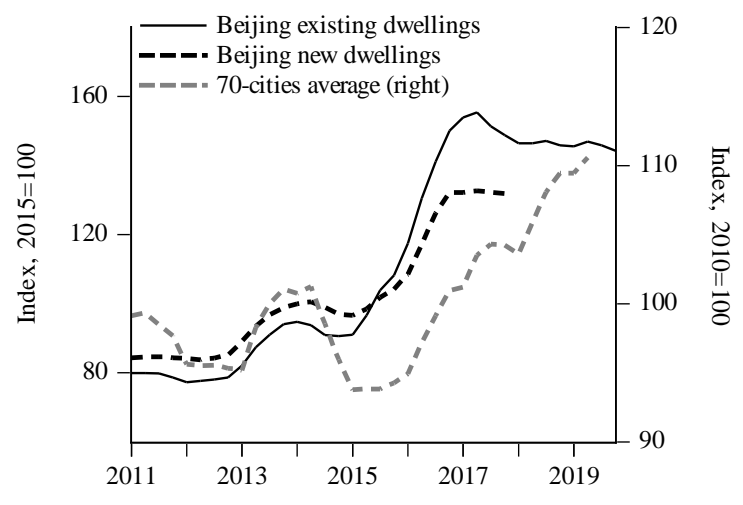

Source: National sources, BIS Residential Property Price database.

The need to address the economic slowdown given weak external demand and the on-going trade war has fallen on fiscal authorities. The Chinese government announced a set of fiscal stimulus policies in the mid-2019 to expand infrastructure investment and authorise local governments to use proceeds from special bonds to finance infrastructure projects. This has led to another round of steel production booms, supporting Australia's exports of bulk commodities.

Monetary policy in China, nevertheless, maintained a relatively neutral stance compared to the synchronised easing in several major central banks in advanced economies.

Absent liquidity expansion, reforms of the transmission mechanism gained momentum in the second half of 2019. In August, the People's Bank of China (PBoC) introduced a reform for the benchmark loan rate - the Loan Prime Rate (LPR) - to better reflect the market demand for credit. ${ }^{3}$ This is widely regarded as an official attempt to revive growth and effectively cut financing costs in the real economy. In October, the PBoC unexpectedly kept the LPR lending benchmark unchanged and then lowered it by 5 basis points in November.

This article is protected by copyright. All rights reserved. 
Despite the government's effort in reining in debt growth, financial risks remain considerable in 2019. Noticeably, household debt picked up pace in 20182019, rising more rapidly than corporate debt (Figure 3).

Figure 3: China's Credit as Percentage of GDP (\%)

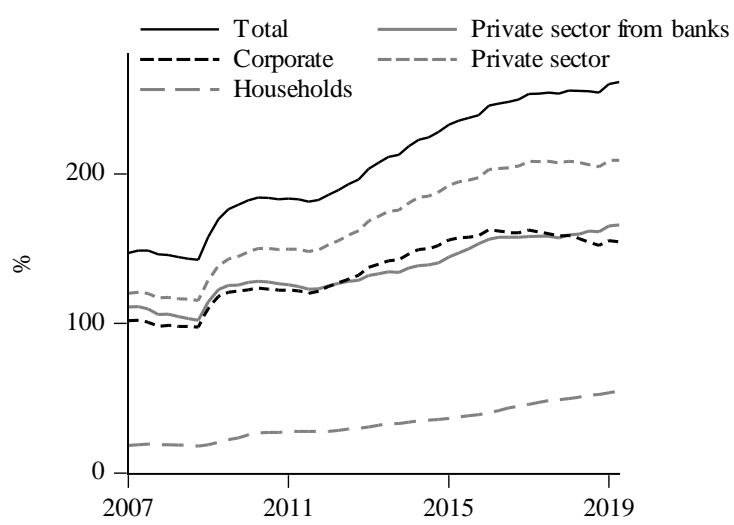

Source: Bank for International Settlements.

\section{Australia}

Overall conditions in the Australian economy weakened considerably over the course of 2019. Output growth was approximately 2 per cent in 2018-19, down from the 2.9 per cent observed in the previous fiscal year and the 2.3 per cent growth during 201617. GDP year-end growth was particularly weak in the March and June 2019 quarters, falling to 1.7 and 1.4 per cent respectively (as compared to consecutive annual growth of 3.1 per cent for the March and June 2018 quarters) (Figure 4). Domestic final demand followed a similar downward trend during 2019. Despite strong gains in 2017-18, with year-ended growth exceeding 3 per cent in every quarter, growth in 2018-19 fell to 1.7 per cent (Figure 4).

The IMF estimates output growth for 2019 to be about 1.8 per cent, down considerably from its prior year forecast of 2.8 per cent (IMF, 2019). The weaker economic growth observed during 2019 reflects caution on the part of consumers and firms thereby dampening both consumption and private sector investment. By comparison, growth in the previous fiscal year was fuelled by greater exports, nonmining business investment and public demand. The decline in economic growth is even bleaker once the effects of population growth are accounted for. In this respect, per-capita output growth fell from 1.3 per cent in 2017-18 to 0.3 per cent in 2018-19. Notably, year-ended growth in per-capita GDP was negative in the March and June quarters of 2019. This is the first time consecutive periods of declining per-capita output have been observed since the GFC (and only the second time since the early 1990s recession).

This article is protected by copyright. All rights reserved. 


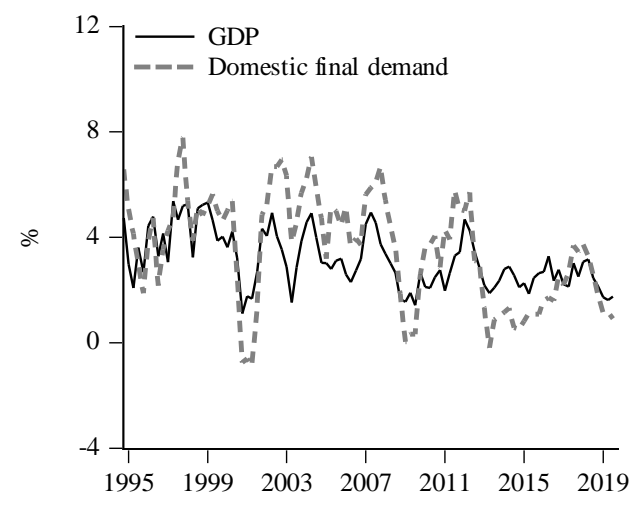

Source: Australian Bureau of Statistics

Although consumption growth grew from 2.4 per cent in 2016-17 to 2.8 per cent in 2017-18, in the most recent fiscal year consumption grew by a relatively weak 1.9 per cent. The falls observed in year-ended consumption growth in the first and second quarters of 2019 were most concerning, with annual growth falling to 1.8 per cent in the March quarter and to a mere 1.4 per cent in the June quarter (Figure 5). This confirms last year's prediction that, without wage growth, the stronger consumption growth in 2017-18 was likely to be short lived (Nguyen and Wang, 2019).

After exhibiting almost double-digit growth rates, residential investment growth declined to 2.6 per cent in 2016-17 and 0.6 per cent in 2017-18. In the most recent fiscal year, residential investment exhibited negative growth (-0.3 per cent). This was fuelled by a particularly sharp fall in the second quarter of 2019 when residential investment declined by almost 10 per cent in year ended terms (Figure 5). Typically, it would be expected that this decline would persist into 2020. However, the presence of record low borrowing costs is likely to reduce the probability of additional sharp falls in residential investment notwithstanding the broader decline in economic growth.

Figure 5: Real Household Consumption and Residential Investment Growth (Year-Ended, \%)

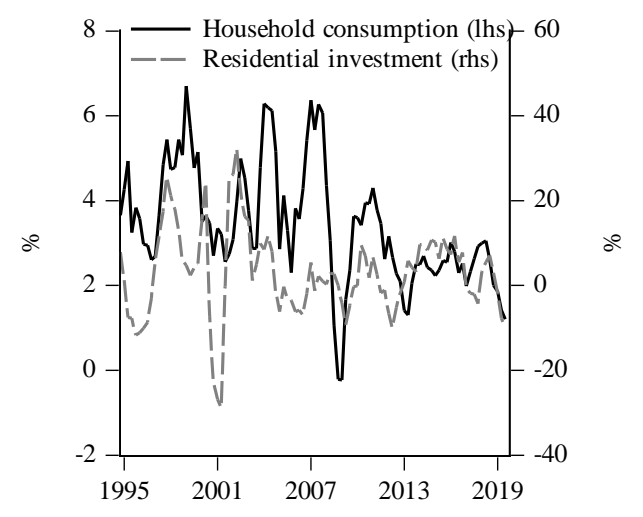

Source: Australian Bureau of Statistics

A clear downward trend is evident in the savings rate, which appears to be moving towards pre-GFC levels. A possible reason for this is that taxes are eroding already small income gains thereby reducing the ability of consumers to both save or

This article is protected by copyright. All rights reserved. 
spend. The current savings rate is well below the 3.8 per cent observed over the 17/18 fiscal year and the 4.9 per cent in the 16/17 fiscal year (Figure 6). This decline is in line with the weak growth of disposable income, which has fallen considerably since the 3.6 per cent average growth observed in the 16/17 fiscal year. In this respect, the absence of any meaningful wage growth is a key issue. Notwithstanding low inflation, weak growth in wages has been a drag on both disposable income and household spending. This is particularly important for discretionary spending.

To better appreciate the magnitude of the decline in the savings rate, Figure 6 shows the household savings rate since 2000. After spiking in 2008 and remaining at elevated values until about 2015, it has since declined significantly. At present, there is little evidence to suggest that this downward trend will change in the short to medium term.

Figure 6: Trend Household Saving Ratio and Debt to Income Ratio (\%)

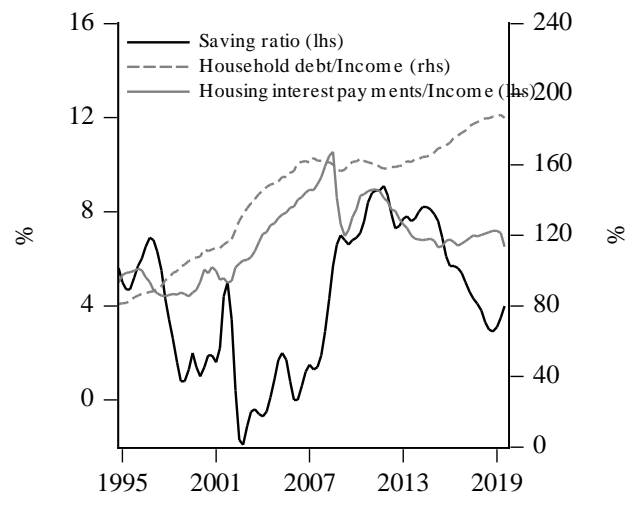

Source: Australian Bureau of Statistics

Some of the decline in the savings rate is expected (as it represents a shift away from the spike observed during the peak of the GFC). However, a key issue to consider is whether the decline is primarily due to mean-reversion (in other words, a return to pre-GFC conditions), or if it is a function of substantive constraints on household spending capacities. Although both are likely to be relevant determinants, the continued weakness in household disposable income growth, coupled with a sharp decline in non-food retail spending, suggests that much of the recent decline in the savings rate is a reflection of constraints on household spending. For example, retail spend data show slower growth in non-food retail spend commencing in 2017. Since then, annual growth in food spend has exceeded that of non-food spend. Recent data indicate that the former is growing at approximately double the rate of the latter. As non-food retail expenditure is a better indicator of the household overall capacity to spend, compared to food retail expenditure, its subdued growth in the past couple of years suggests tighter constraints on household spending. It is likely that the current primary factor driving the decline is not related to falling risk aversion but to weak growth in household income which curbs the capacity of (lower income) households to save.

This article is protected by copyright. All rights reserved. 
Over the course of 2018-19, housing interest payments as a share of disposable income continued their slow but steady rise. This is consistent with the observed rise in the household debt to income ratio, which is now at about 190 relative to 180 during the 16/17 fiscal year (Figure 6). At the same time, steadily falling housing prices have curbed household wealth, leading to meaningful falls in housing asset to income ratios (although these have been partially offset by rising financial markets). The rate cuts in 2019 will likely reduce pressure on interest payments in the short to medium term (possibly leading to a divergence - at least in the short term - between the housing interest payments to disposable income ratio and the housing asset to income ratio).

\subsubsection{Business Investment}

Business investment growth was negative in 2018-19, falling from a rise of approximately 6.4 per cent in the prior fiscal year to -1.3 per cent (Figure 7). To better gauge the magnitude of current investment, it is noted that business investment as a share of GDP is currently below 12 per cent, and therefore at its lowest level since the early 1990s downturn. This decline has been driven by falls in investment pertaining to machinery, equipment and engineering, whereas building related investment has remained relatively static in terms of its share in nominal GDP.

As is evident in Figure 7, the mining sector has been instrumental in terms of the role that investment has played in economic growth. Although non-mining investment has been steadily rising (growing by about 6.5 per cent in 2018), mining investment has declined dramatically since 2012. In 2018, mining investment fell by about 10 per cent.

Figure 7: Non-Mining and Mining Business Investment Growth (Year-Ended, \%)

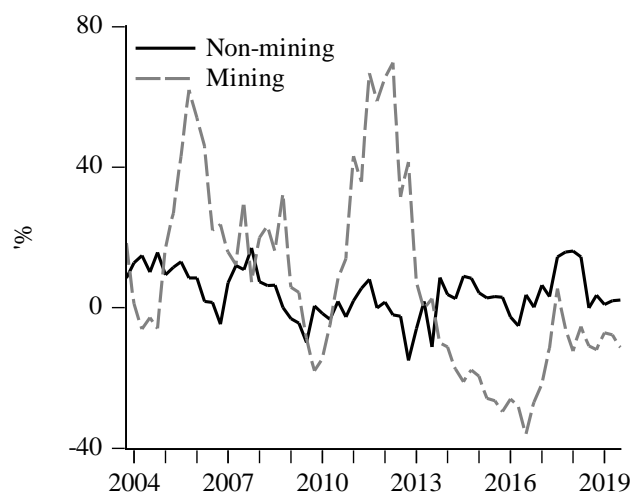

Sources: Australian Bureau of Statistics

In 2019-20, non-mining business investment appears to have slowed in line with the broader economic decline and concerns about future economic growth. Recent survey estimates from the NAB Monthly Business Survey suggest that non-mining business investment is likely to be at average or below average levels for most industries.

This article is protected by copyright. All rights reserved. 
By comparison, NAB survey data and ABS data on new mining related capital expenditure suggest that the decline in mining investment is likely to have bottomed out. This view is also consistent with Jenner et al. (2018) who argue in favour of a pick-up in mineral exploration activity. It is important to exercise caution, however, given the large level of volatility historically observed in investment growth (particularly that related to mining investment). Since 2002, annual growth in mining investment has exhibited a level of volatility of about 25 per cent rendering any forecasts tenuous at best.

\subsubsection{Terms of Trade, Exchange Rate}

The exchange rate as measured by the trade-weighted index (TWI) followed a downward trend in 2018-19, whereas Australia's terms of trade, the relative prices of exports to imports, strengthened in 2018-19, largely due to increased commodity prices. Most recently, the iron ore prices rose to their highest level since early 2014, due to a combination of negative supply shocks (due to disruptions in Brazil) and increased infrastructure investment in China.

Australia's exports of goods and services grew relatively strongly in 2018-19, with year-ended growth for exports of goods peaking at 24 per cent in November and exports of services peaking at 13 per cent in December last year. Resources exports are expected to grow into 2020, as are services exports supported by a strong demand for Australia’s education sector (RBA 2019).

By comparison, import growth was relatively weak in 2018-19 relative to the growth observed in 2017 and the first half of 2018. The limited growth in imports largely reflects weak domestic demand in 2019.

\subsection{Labour}

Despite early hopes of a fall in the unemployment rate, the Australian labour market further deteriorated over the course of 2019. The unemployment rate commenced the year at 5.0 per cent, but rose to 5.2 per cent in the second quarter, and again to 5.3 per cent in the third quarter of 2019 (Figure 8). The increase in the unemployment rate is associated with a greater participation rate, which averaged 65.7 per cent in the first quarter of 2019, rising to 66.0 and 66.1 per cent in the next two quarters. A possible rationale for this is that older Australians are seeking employment as a means of countering the income effects of record low interest rates.

The increase in the unemployment rate also has ramifications for wage inflation, particularly given the argument that the NAIRU (Non-Accelerating Inflation Rate of Unemployment) has fallen to between 4 to 4.5 per cent. This rate is consistent with RBA estimates of the current NAIRU (Ellis, 2019), although some estimates point to a value as low as 3.3 per cent (Lye and McDonald, 2019). As a point of comparison, the estimated time-varying equilibrium unemployment rate was about 5.0 per cent prior to the GFC (Lim, Dixon and Tsiaplias, 2009).

This article is protected by copyright. All rights reserved. 
In line with higher unemployment, year-ended employment growth was about 3.0 per cent in 2017-18 but fell heavily to 2.4 per cent in 2018-19. Annual employment growth is expected to decline further in 2019-20 to about 2.1 per cent.

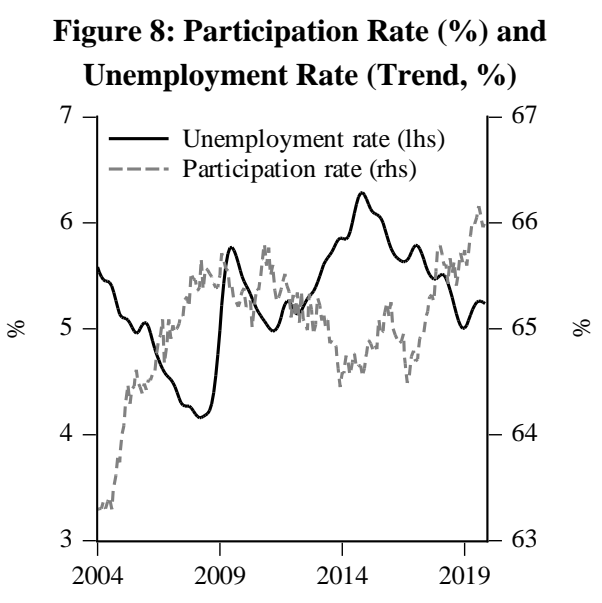

Source: Australian Bureau of Statistics.

The decline in employment growth occurred for both full and part time employment suggesting that it is not attributable to the full or part time distinction. To better assess this, we also examined industry-specific trends in employment between August 2018 and August 2019.

The largest increase was in the professional, scientific, and technical services industry, followed by the education and training sector (see Table 2). By comparison, two years ago (during the housing boom), employment growth was largest in the health care and social assistance and construction industries. At the opposite end of the spectrum, the manufacturing industry experienced a severe decline in employment growth (almost entirely concentrated in the loss of full-time jobs).

Table 3 shows that the additional employment in the professional, scientific and technical services industry was primarily based in Victoria (and to a lesser extent Western Australia). Similarly, the bulk of the additional jobs in the education and training sectors were also in Victoria. About half of the job losses in manufacturing were in NSW, with a quarter based in Queensland (although these were offset by commensurate growth in health-related jobs in both states).

\subsection{Wages and Inflation}

Wage growth has remained weak for several years. In 2018-19, wages rose by 2.3 per cent for the private sector and 2.5 per cent for the public sector. These values were slightly higher than their corresponding rates in 2017-18 (2.0 and 2.4 per cent) but the difference is negligible.

Although wage growth has been trending downwards since the GFC, a material fall in wage growth was observed from about 2014 onwards. Since 2014, wage growth has persistently failed to exceed 3 per cent. In so doing, real wage growth has effectively been at zero for the past five or so years. Overall, growth in the Wage Price Index - the main measure of wages that policymakers look at - has hovered around its lowest rate since the late 1990s (Figure 9).

This article is protected by copyright. All rights reserved. 


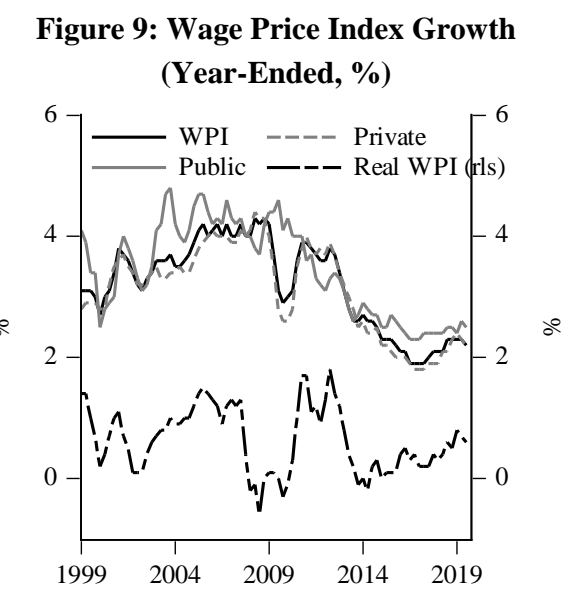

Source: Australian Bureau of Statistics.

A key contributor to weak wages growth is the presence of both low inflation and low inflationary expectations. Inflation in 2019 has persistently failed to meet the lower bound of the Reserve Bank's 2 to 3 per cent target. This result holds for both headline and the three core measures of inflation (trimmed mean, weighted mean and inflation excluding volatile items) indicating that low price growth is a general phenomenon.

Similarly, measures such as the Melbourne Institute's Consumer Inflationary Expectations index and the implied difference between indexed and nominal bonds) (Figure 10) also point to relatively weak price growth going forward. With inflation expected to remain low in 2019-20, there is little evidence to counter the argument that, at least in the short term, real wage growth will remain close to zero.

Figure 10: Inflation expectations (Year-Ended, \%)

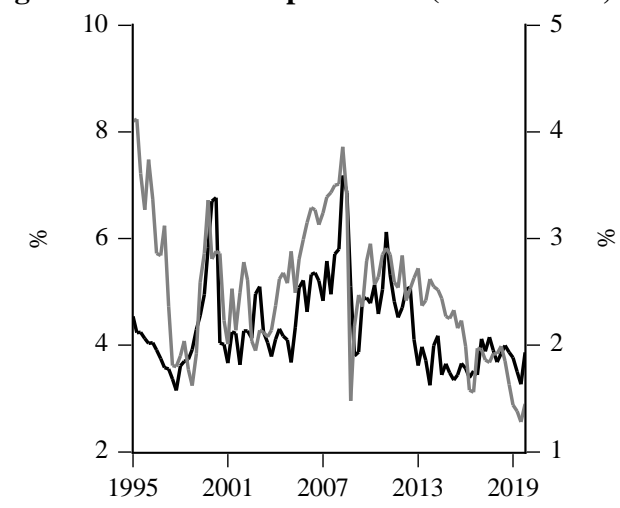

Note: Melbourne Institute measure is a 30 per cent trimmed mean.

Sources: Melbourne Institute, Reserve Bank of Australia

\subsection{Financial Markets}

The confluence of weak domestic inflation and wage growth, cautious consumers and a global shift towards more accommodative monetary policy had a significant impact on the Reserve Bank Board's decisions in 2019. Despite initial expectations of a potential shift to a more restrictive monetary policy, the Reserve Bank Board cut its cash rate target in June, July and October resulting in a target rate of only 0.75 per cent.

This article is protected by copyright. All rights reserved. 
Despite possible concerns of a potential re-heating of the housing market, the recent cuts indicate broader - and more pressing - concerns about global and local economic conditions. At this stage, there is relatively little room to move for monetary policy and it is difficult to envisage that any further rate cuts will induce any meaningful incremental nudge to the decision making of consumers and firms (to spend and invest). On a positive note, to date there is little evidence that the rate cuts have induced sharp rises in consumer price inflation.

Banks have been hesitant to fully pass-on the interest rate cuts to mortgage rates. Although mortgage rates have fallen to historically low levels (Figure 11), they are nevertheless greater than the level implied by fully passing through rate cuts. This is unsurprising with evidence suggesting that pass-through rates are time-varying and depend heavily on funding costs (Lim, Chua and Tsiaplias, 2009). On this basis, it seems unlikely that any further rate cuts by the Reserve Bank Board will be fully reflected in mortgage rates.

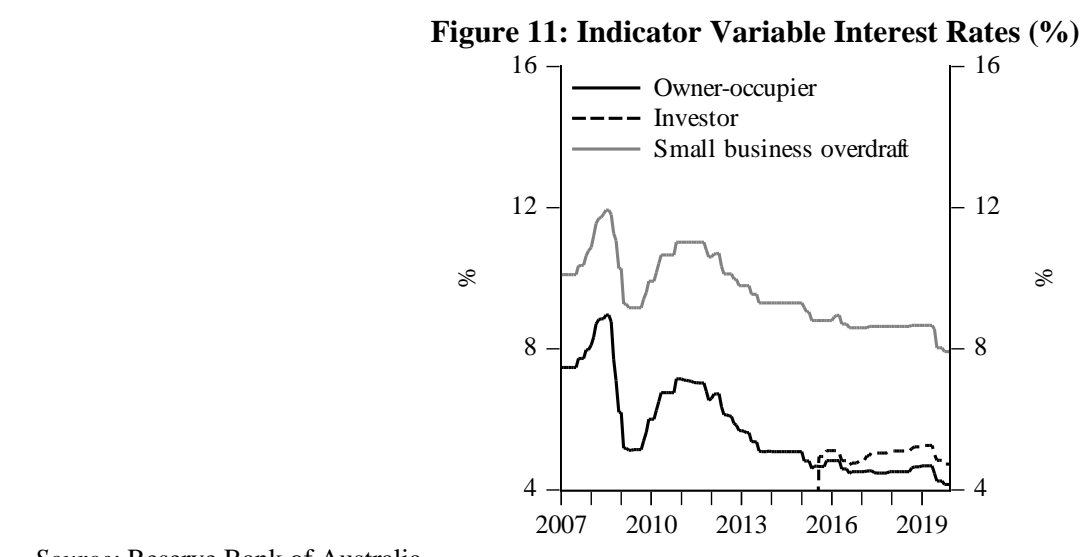

Source: Reserve Bank of Australia.

In line with declining house prices and housing transaction volumes, housing credit growth also declined sharply in 2019. Annual growth in housing finance remains

at levels not seen since the sharp drop observed during the GFC (Figure 12). Recent data, however, suggests a possible bottoming out with June quarter growth rising to 14.6 per cent (from -15.8 and -15.3 in the preceding two quarters). Recent rate cuts should lead to at least some improvement in housing finance growth rates.

Figure 12: Housing Credit Growth

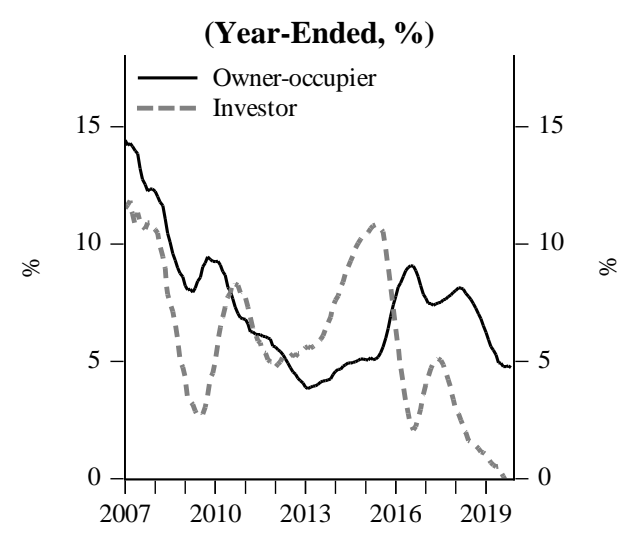

This article is protected by copyright. All rights reserved. 
Source: Reserve Bank of Australia.

The decline in housing finance is likely to be attributed to both a fall in housing market activity and the imposition of more stringent borrowing conditions by banks. In terms of the latter, as a result of factors such as the Royal Commission into the banking, superannuation and financial services industries, some lenders appear to have amended existing lending processes (for example, requiring additional information for the provision of a loan) thereby making it more difficult to obtain a loan. It is, however, unclear whether these restrictions are temporary.

Table 2: Employment by industries ('000): full-time (FT) and part-time (PT)

\begin{tabular}{|c|c|c|c|c|c|c|c|c|c|}
\hline & \multicolumn{3}{|c|}{$\begin{array}{c}\text { Change between } \\
\text { Aug } 2017 \text { - Aug } 2018\end{array}$} & \multicolumn{3}{|c|}{$\begin{array}{c}\text { Change between } \\
\text { Aug } 2018 \text { - Aug } 2019 \\
\end{array}$} & \multicolumn{3}{|c|}{$\%$ part-time } \\
\hline & FT & PT & Total & FT & PT & Total & $\begin{array}{l}\text { Aug } \\
2017 \\
\end{array}$ & $\begin{array}{l}\text { Aug } \\
2018\end{array}$ & $\begin{array}{l}\text { Aug } \\
2019\end{array}$ \\
\hline Agriculture, forestry, fishing & -8 & 0 & -8 & 3 & -6 & -2 & $26 \%$ & $26 \%$ & $25 \%$ \\
\hline Mining & 34 & -2 & 33 & -10 & -1 & -11 & $5 \%$ & $3 \%$ & $3 \%$ \\
\hline Manufacturing & 72 & 13 & 85 & -100 & 1 & -99 & $16 \%$ & $16 \%$ & $18 \%$ \\
\hline Electricity, gas, water, waste services & 0 & 5 & 6 & 11 & 7 & 18 & $9 \%$ & $12 \%$ & $15 \%$ \\
\hline Construction & 14 & 16 & 30 & -5 & -3 & -7 & $15 \%$ & $16 \%$ & $16 \%$ \\
\hline Wholesale trade & -8 & -2 & -10 & 34 & 13 & 47 & $17 \%$ & $17 \%$ & $18 \%$ \\
\hline Retail trade & -32 & 22 & -10 & 13 & -5 & 8 & $50 \%$ & $53 \%$ & $50 \%$ \\
\hline Accommodation, food services & -16 & 3 & -13 & 3 & 30 & 33 & $59 \%$ & $63 \%$ & $63 \%$ \\
\hline Transport, postal, warehousing & -12 & 16 & 3 & 35 & -9 & 26 & $20 \%$ & $22 \%$ & $20 \%$ \\
\hline $\begin{array}{l}\text { Information media, } \\
\text { telecommunications }\end{array}$ & -1 & 3 & 2 & -10 & 0 & -10 & $20 \%$ & $22 \%$ & $23 \%$ \\
\hline Financial, insurance services & 37 & -1 & 35 & -13 & 4 & -10 & $18 \%$ & $16 \%$ & $18 \%$ \\
\hline Rental, hiring, real estate services & 10 & 6 & 16 & -3 & -3 & -5 & $23 \%$ & $24 \%$ & $23 \%$ \\
\hline Professional, scientific, technical ser. & 42 & 24 & 66 & 98 & -4 & 94 & $23 \%$ & $23 \%$ & $21 \%$ \\
\hline Administrative, support serv. & 13 & -18 & -4 & 41 & 34 & 75 & $48 \%$ & $43 \%$ & $43 \%$ \\
\hline Public administration, safety & 74 & 11 & 86 & -17 & 0 & -17 & $18 \%$ & $17 \%$ & $18 \%$ \\
\hline Education, training & -1 & -7 & -9 & 54 & 29 & 84 & $40 \%$ & $40 \%$ & $40 \%$ \\
\hline Health care, social assistance & -10 & 17 & 6 & 41 & 25 & 66 & $43 \%$ & $45 \%$ & $45 \%$ \\
\hline Arts, recreation services & 10 & -2 & 7 & 1 & -2 & -1 & $50 \%$ & $48 \%$ & $48 \%$ \\
\hline Other services & -22 & 3 & -20 & 11 & 15 & 26 & $31 \%$ & $33 \%$ & $34 \%$ \\
\hline Total (Industries) & 196 & 106 & 302 & 186 & 126 & 312 & $31 \%$ & $32 \%$ & $32 \%$ \\
\hline
\end{tabular}

This article is protected by copyright. All rights reserved. 
Source: ABS, Labour Force, Australia, Detailed, Quarterly, August 2019, Table EQ05

Table 3: Employment by industries and states: Jobs added (Jobs, ‘000) and Industry Share (Share, \%)

\begin{tabular}{|c|c|c|c|c|c|c|c|c|c|c|}
\hline & \multicolumn{5}{|c|}{$\begin{array}{l}\text { Change in employment } \\
\text { between Aug } 2018 \text { - Aug } 2019\end{array}$} & \multicolumn{5}{|c|}{ Employment share by Industry } \\
\hline & NSW & VIC & QLD & SA & WA & NSW & VIC & QLD & SA & WA \\
\hline Agriculture, forestry, fishing & 16 & -24 & 15 & -6 & -8 & 2.2 & 2.1 & 2.9 & 3.7 & 2.5 \\
\hline Mining & -13 & 0 & -8 & 1 & 10 & 0.8 & 0.3 & 2.4 & 1.2 & 8.6 \\
\hline Manufacturing & -52 & -14 & -25 & -5 & 1 & 6.0 & 8.1 & 6.5 & 7.4 & 6.2 \\
\hline Electricity, gas, water, waste services & 7 & 10 & -1 & 0 & 4 & 1.1 & 1.3 & 1.3 & 1.6 & 1.6 \\
\hline Construction & -17 & -10 & 14 & 5 & 1 & 8.9 & 9.0 & 9.8 & 9.2 & 9.0 \\
\hline Wholesale trade & 7 & 20 & 8 & 4 & 4 & 3.2 & 3.6 & 3.2 & 3.0 & 3.0 \\
\hline Retail trade & 1 & 13 & -15 & -2 & 14 & 9.6 & 10.0 & 9.2 & 9.9 & 9.9 \\
\hline Accommodation, food services & 59 & -6 & 7 & -2 & -18 & 7.7 & 6.2 & 7.6 & 7.5 & 5.6 \\
\hline Transport, postal, warehousing & 25 & 8 & -9 & -1 & 5 & 5.6 & 5.0 & 5.4 & 4.5 & 5.4 \\
\hline $\begin{array}{l}\text { Information media, } \\
\text { telecommunications }\end{array}$ & -11 & -6 & 7 & 1 & -2 & 1.9 & 1.9 & 1.4 & 1.4 & 0.9 \\
\hline Financial, insurance services & -10 & 6 & -8 & -5 & 7 & 4.8 & 3.9 & 2.2 & 2.0 & 2.3 \\
\hline Rental, hiring, real estate services & -17 & 5 & 6 & -2 & 3 & 1.5 & 1.5 & 2.0 & 1.2 & 1.7 \\
\hline Professional, scientific, technical ser. & -14 & 71 & 2 & 8 & 24 & 10.0 & 10.5 & 7.0 & 7.2 & 8.4 \\
\hline Administrative, support serv. & 39 & 20 & 15 & 5 & -7 & 3.8 & 3.7 & 3.8 & 3.7 & 2.9 \\
\hline Public administration, safety & 27 & 14 & -23 & -16 & -13 & 5.6 & 5.6 & 5.8 & 5.7 & 5.9 \\
\hline Education, training & 10 & 42 & -13 & 21 & 13 & 8.0 & 9.1 & 8.5 & 9.5 & 8.5 \\
\hline Health care, social assistance & 55 & -22 & 31 & 9 & -8 & 13.7 & 12.5 & 14.4 & 15.9 & 12.3 \\
\hline Arts, recreation services & -7 & -2 & 11 & -5 & 0 & 1.8 & 2.1 & 1.9 & 1.2 & 1.8 \\
\hline Other services & 21 & -7 & 20 & 5 & -12 & 3.9 & 3.5 & 4.7 & 4.2 & 3.5 \\
\hline Total (Industries) & 126 & 117 & 34 & 15 & 19 & 100 & 100 & 100 & 100 & 100 \\
\hline
\end{tabular}

Source: ABS, Labour Force, Australia, Detailed, Quarterly, August 2018, Table EQ03

\section{Housing markets, financial stability and consumers}

\subsection{The Banking Royal Commission announced its recommendations in early 2019}

The Royal Commission into the banking, superannuation and financial services industries formally announced its recommendations in 2019. The final report made a number of key recommendations concerning bank lending and the provision of

This article is protected by copyright. All rights reserved. 
financial advice, in addition to recommendations regarding the superannuation and insurance sectors.

In terms of home lending, the Royal Commission recommended the amendment of laws pertaining to both the advice provided by mortgage brokers and the remuneration of mortgage brokers. The recommendations are potentially far reaching since it is estimated that mortgage broking accounts for about half of all residential loans. The existing remuneration scheme for mortgage brokers is likely to have produced non-negligible distortions in the market for housing loans. To date, brokers have often received a combination of initial payments and on-going payments (or trailing commissions) for introducing customers to banks. In effect, under existing arrangements, brokers often continue to receive commissions even after a loan has been arranged, notwithstanding that they are no longer providing any service to the borrower.

Given the provision of these commissions, brokers have historically had a significant motivation to recommend loan products that provide large commissions even if these are not in the interests of borrowers. Moreover, brokers have had little incentive to advise any changes to existing borrowing arrangements since such changes may interfere with their entitlement to trailing commissions.

The recommendations, which the Federal government accepted in principle prior to the 2019 elections, aim to ban trailing commissions and other inappropriate payments made by banks to mortgage brokers. At the same time, however, they do not attempt to unlink banks from promoting financial products or providing financial advice. An area of concern is that here remains significant uncertainty about the extent to which the recommended changes (or, more aptly, the future legislation that will bring effect to the recommendations) will change systemic cultural practices (for both banks and brokers) that are at the core of the issues and case studies discussed in the report.

\subsection{First home buyer activity sees a resurgence}

In 2017 the NSW and Victorian governments announced significant first home buyer stamp duty deductions. Pursuant to these announcements, first home buyers in NSW received stamp duty exemptions for dwellings up to $\$ 650,000$ and stamp duty concessions for homes up to $\$ 800,000$. In Victoria, similar exemptions were applicable for houses up to $\$ 600 \mathrm{k}$ with concessions provided for homes up to $\$ 750,000$.

In the initial months following the announced deductions, we observed a surge in the proportion of first home buyers in NSW and Victoria. In NSW, the proportion rose from 8.8 per cent in June 2017 to 13.8 per cent in September 2017. Over the same period, the proportion of first home buyers in Victoria rose by 4.1 percentage points to 18.5 per cent.

Since then, there was a plateauing in first home owners rates up until mid-2019. In the second half of 2019, following a period of substantial declines in house prices (Figure 13), together with the curbing of investor credit, we saw a second round of first home buyer activity (Figure 14). The proportion of first home owners rose to 
about 17 per cent in NSW and 21 per cent in Victoria (with investment activity declining, NSW and Victorian first home buyer proportions in the latter half of 2019 reached their highest levels since 2012).

Figure 13: House prices (annual percentage change)

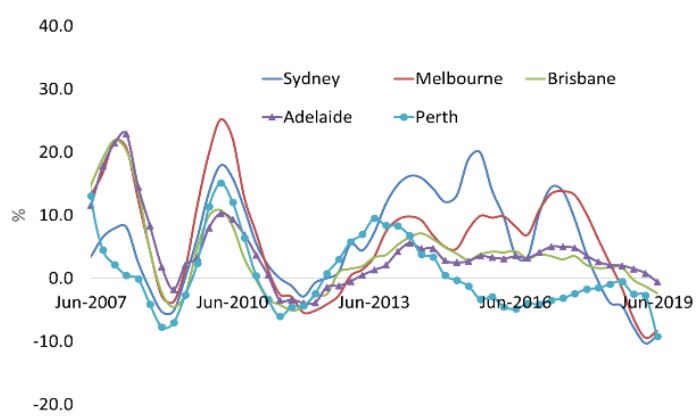

Source: ABS.

Looking forward, the Federal Government's mortgage guarantee scheme (announced during the 2019 election) is likely to have a small incremental effect on first home buyer activity. Pursuant to this scheme, eligible first-home buyers, with at least a 5 per cent deposit for a home, will be able to qualify for a loan (and avoid paying the usual mortgage insurance required for relatively high LVR borrowers). A key issue with such schemes, however, is that they tend to prop up demand for lowerend and/or higher-density dwellings, generating excess demand in the lower tail of the price distribution. Moreover, there may be a potential conflict between the scheme and the financial stability measures described in the Royal Commission. The guarantee may be encouraging first-home buyers to take on mortgages with high loan to valuation ratios.

Figure 14: Proportion of first home buyers

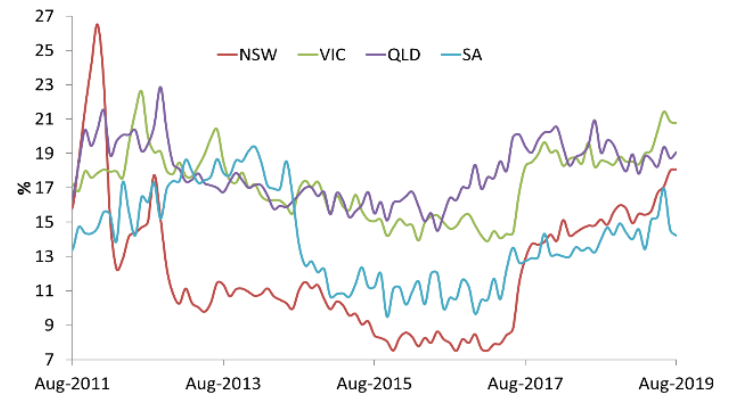

Source: ABS.

This article is protected by copyright. All rights reserved. 


\subsection{Has the housing landscape changed over the past 25 years?}

In the lead-up to the 2019 Federal election, there was significant discussion regarding the price of housing access and the on-going suitability of tax breaks for housing. Labour party policies focused on the cutting back of negative gearing for new investors, while the Liberal party proposed a small-scale scheme whereby eligible first-home buyers, with at least a 5 per cent deposit for a home, would be able to qualify for a loan.

Amidst this discussion, and in light of the continued presence of relatively high house prices (notwithstanding the declines over the past year), recent data released by the ABS allows us to examine trends in the general housing landscape over the past 25 years thereby providing some useful context for the broader discussion on housing affordability.

Figure 15 shows how the proportion of households that are renters has changed since 1994. Key historical differences (such as the presence of a relatively high proportion of renters in Queensland) continue to be observed. In all states, however, there is an obvious positive trend in rental proportions. In the two largest states, the proportion of renters has increased by an average of 0.4 percentage points per annum over the past 25 years, from about 18 per cent of households in 1994/95 to 27 per cent in $2017 / 18$.

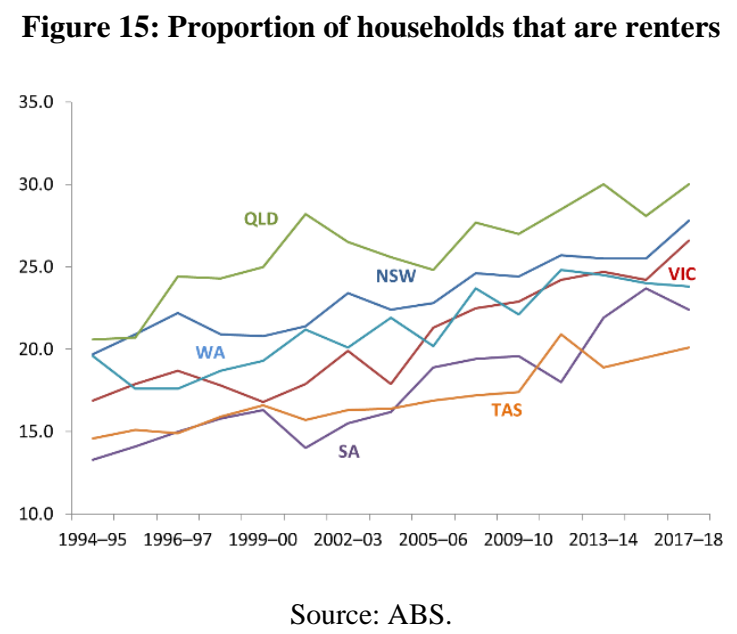

An even clearer positive trend is observed in the proportion of households with a mortgage. Figure 16 shows a comparably small degree of variation in mortgage proportions across the states, in addition to a strong positive trend. As is the case with rental proportions, certain key features - such as the relatively high proportion of mortgagors in Western Australia - are persistently observed in the data. On average, the proportion of mortgagors has risen from about 30 per cent of households to approximately 38 per cent of households. Taken together, the trends mean that the percentage of all households who are debt-free owner occupiers has fallen from 44 per cent to 30 per cent.

This article is protected by copyright. All rights reserved. 


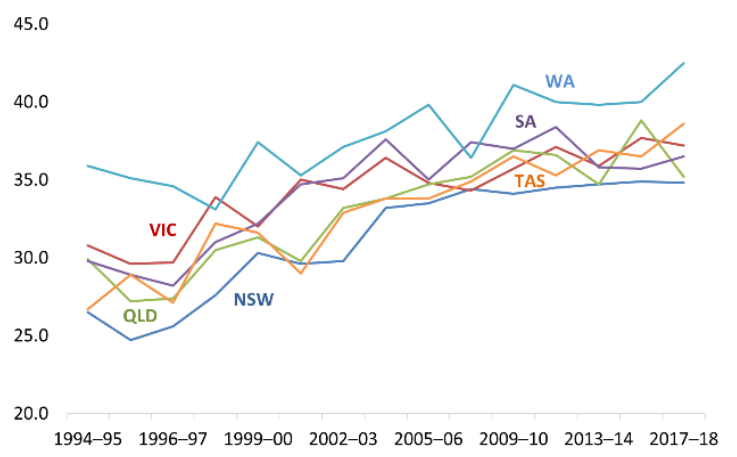

Source: ABS.

The substantial increases in renter and mortgagor proportions indicate that a record proportion of households are now facing significant housing-related costs. To better understand this, note that housing costs (on average) for owners without mortgages constituted a relatively negligible 3 per cent of gross household income in 2017/18 (according to the ABS Survey of Income and Housing). In contrast, average housing costs for renters or mortgagors were about 17 per cent of gross household income.

For many households, an increasingly greater proportion of overall household expenditure is therefore being allocated to housing costs. This is likely to have influenced (and will continue to influence) household expenditure on goods other than housing, particularly goods of a discretionary nature which are likely to be curtailed to pay for housing costs. This is also consistent with recent trends in retail spend data showing that food-related expenditure is relatively high compared to non-food expenditure.

In attempting to offset recent relatively low inflation and wages growth, the RBA has recently cut back its cash rate to 0.75 per cent. There is some evidence suggesting that lowering credit costs has historically been associated with increased speculation in housing (and financial) markets, primarily by influencing the typical relationship observed between prices and fundamentals (Lim and Tsiaplias, 2018). In the current economic climate, it is likely that the recent easing will curb any further house price depreciation that may otherwise have taken place. As such, house prices (and house price to income ratios) are likely to remain high.

To get a better picture of future housing market conditions, we examine the Melbourne Institute's Dwelling Sentiment Index. This index is derived based on answers provided by consumers regarding whether they believe it is a good time to buy a dwelling. Figure 17 shows that dwelling sentiment improved in 2019, with the index crossing above its 5-year average of 106 and its overall average of 117 (since 
1996). As such, following on from the federal election and the recent rate cuts, housing market sentiment appears to have improved by a substantial margin.

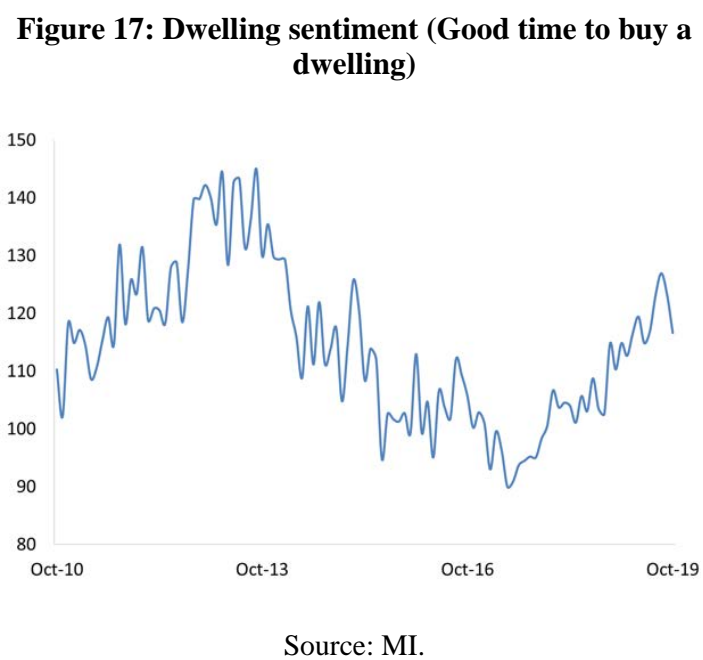

Another useful forward-looking measure of housing market stability is the extent to which consumers expect inordinate house price changes. To measure this, we use the Melbourne Institute's House Price Expectations Index and focus on the extent to which individuals expect house prices to fall by more than 10 per cent.

In July 2019, a little over 3 per cent of consumers believed that house prices would exhibit annual falls of more than 10 per cent (Figure 18). This is considerably lower than the record 7 per cent of consumers who believed that house prices would exhibit $10^{+}$per cent falls in February (or the 5 per cent in May). Although the proportion of consumers expecting large falls has declined, it is still greater than the historical average of about 2.5 per cent (or the 5-year average of 2.7 per cent). Overall, however, the survey results indicate that most consumers believe that the worst of the housing market decline was observed in the first quarter of 2019.

This article is protected by copyright. All rights reserved. 
Figure 18: Proportion of respondents expecting house prices to fall by more than 10 per cent

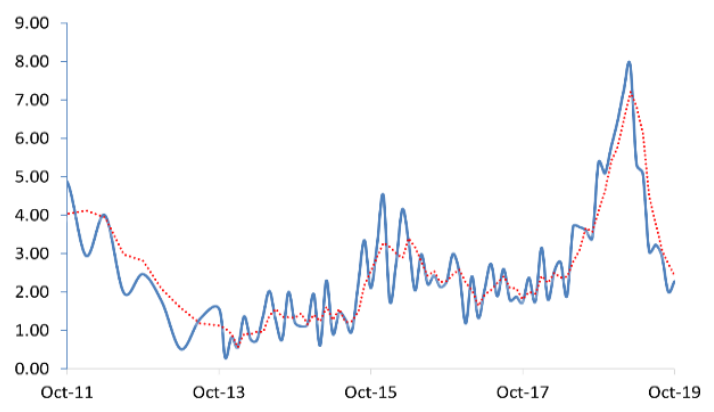

Source: MI. Red dashed line is 3-mth moving average.

\section{Concluding Remarks}

Growth in the economy is expected to average below 2 percent over the two-year period covering 2019 and 2020. Consumption growth is also expected to remain weak at 1.5 per cent in 2020, notwithstanding the substantial rate cuts undertaken in 2019. There are also three significant downside risks to these forecasts.

The first significant downside risk is that the absence of a resolution to the trade war between the US and China also poses risks for the Australian economy. In this respect, there is a possibility that the trade war will reduce Chinese economic growth thereby negatively affecting the Australian economy.

Another key downside risk is that wage growth may be lower than expected. The Reserve Bank's current thesis is that lower unemployment rates are needed to push wages up, but there is significant uncertainty about the lags associated with the implied mechanisms underpinning this model. Low wage growth will impact negatively on demand, in addition to further increasing the probability of another year of inflation below the Reserve Bank’s target band.

Finally, there is a downside risk that consumers respond to lower rates in a manner that predominantly facilitates asset price appreciation. This type of reaction has been observed in Australia before (Lim and Tsiaplias, 2018) and is likely to draw away from consumption expenditure, placing additional pressure on other parts of the economy.

December 2019

This article is protected by copyright. All rights reserved. 


\section{Endnotes}

1. As at December 2019 the US and China reached a temporary trade deal. The "phase one" deal entails that China will buy more high-quality agricultural products from the US and allow the American financial services into the Chinese market while the US will halve the imposed 15 per cent tariff and postpone further tariff that was scheduled for December.

2. The structural de-leveraging policies were first mentioned in April 2018 in the meeting of the Central Financial and Economic Affairs Commission. The policies are designed to reduce the leverage ratio of state-owned enterprises and local governments, without affecting the credit ratio of private enterprises.

3. The LPR is an interest rate that commercial banks charge their best clients. The new LPR will be linked to rates set during the PBOC's open market operations, which is directly determined by broader financial system demand for central bank liquidity.

\section{References}

Asia Pacific Consensus Forecasts, A Digest of Economic Forecasts, November 2019, published by Consensus Economics Inc., https://www.consensuseconomics.com/publications/asia-pacific-consensus-forecasts/

Bems, Rudolfs, Robert C. Johnson, and Kei-Mu Yi. "Vertical linkages and the collapse of global trade." American Economic Review 101, no. 3 (2011): 308-12.

Ellis, L. (2019) 'Watching the Invisible,' 2019 Freebairn Lecture in Public Policy University of Melbourne, 12 June 2019, https://www.rba.gov.au/speeches/2019/sp-ag-2019-06-12-2.html.

International Monetary Fund (IMF) 2019, World Economic Outlook, Washington, October.

Jenner K, A Walker, C Close and T Saunders (2018), 'Mining Investment Beyond the Boom', RBA Bulletin, March 2018. <https://www.rba.gov.au/publications/ bulletin/2018/mar/mining-investment-beyond-theboom.html>.

Lim, G.C, Dixon, R. and S Tsiaplias, 'Phillips Curve and the Equilibrium Unemployment Rate,' Economic Record, 2009, 85(271), 371-382.

Lim, G.C, Chua, C.L. and S Tsiaplias (2009), 'Bank and Official Interest Rates: How Do They Interact over Time?’ Economic Record, 2013, 89(285), 160-174,

Lim, G.C and S Tsiaplias (2018), 'Interest Rates, Local Housing Markets and House Price Over-reactions,' Economic Record, 94(S1), 33-48.

Nguyen V.H, and J. Wang (2019) 'The Australian Economy in 2018-19: Convergence in Economic Activity across Australia’, The Australian Economic Review, vol. 52, no. 1, pp. 5-18.

Lye J.N. and I.M. McDonald (2019) ‘Can loss aversion shed light on the deflation puzzle?’, CAMA WP 40/2019.

Reserve Bank of Australia (2019) ‘Statement on Monetary Policy’, August 2019.

Robinson T., and J. Wang (2018) 'The Australian Economy in 2017-18: The Importance of Stronger Non-Mining Business Investment Growth’, The Australian Economic Review, vol. 51, no. 1, pp. 5-20. 


\section{University Library}

\section{- M M N E R VA A gateway to Melbourne's research publications}

Minerva Access is the Institutional Repository of The University of Melbourne

Author/s:

Tsiaplias, S;Wang, J

Title:

The Australian Economy in 2019-20: Slower Growth, Record Low Interest Rates and a Changing Housing Landscape

Date:

2020-03-01

Citation:

Tsiaplias, S. \& Wang, J. (2020). The Australian Economy in 2019-20: Slower Growth, Record Low Interest Rates and a Changing Housing Landscape. The Australian Economic Review, 53 (1), pp.5-21. https://doi.org/10.1111/1467-8462.12367.

Persistent Link:

http://hdl.handle.net/11343/276834 